I N F ORM A T I K

Jurnal Informatika, Manajemen dan Komputer, Vol. 9, No. 2, Desember 2017

eISSN : 2580-3042

pISSN : 1979-0694

\title{
PENENTUAN POLA YANG SERING MUNCUL UNTUK PENJUALAN PUPUK MENGGUNAKAN ALGORITMA FP-GROWTH
}

\author{
Chandra Eri Firman \\ Akademi Manajemen Informatika \& Komputer (AMIK) Dumai \\ Jl. Utama Karya Kel. Bukit Batrem Kec. Dumai Timur, Dumai-Riau 28811 \\ email: chandra.eri@gmail.com
}

\begin{abstract}
ABSTRAK
Aturan asosiasi dengan melakukan analisis suatu transaksi penjualan. Analisis transaksi penjualan bertujuan untuk merancang strategi yang efektif dengan memanfaatkan data transaksi penjualan produk pupuk yang dibeli oleh konsumen. Association rule adalah teknik data mining untuk mencari hubungan antar-item dalam suatu dataset yang ditentukan dengan menggunakan Algoritma FPGrowth. Frequent Pattern Growth (FP-Growth) adalah salah satu alternatif algoritma yang dapat digunakan untuk menentukan himpunan data yang paling sering muncul (frequent itemset) dalam sebuah kumpulan data. Algoritma FP-Growth menggunakan konsep pembangunan tree dalam pencarian frequent itemsets. Dari perhitungan nilai confidence dari rule yang dihasilkan menggunakan Rapidminer-studio 7.3.0.
\end{abstract}

Kata Kunci : Data Mining, Assosiation Rule, FP-Growth, Penjualan Produk

\section{PENDAhuluan}

Perkembangan teknologi informasi saat ini menjadikan suatu informasi sebagai elemen yang penting dalam perkembangan masyarakat. Penyajian informasi tidak sepadan dengan kebutuhan informasi yang sangat tinggi, sehingga informasi tersebut perlu digali lebih dalam dari data yang jumlahnya besar. Penggalian suatu informasi atau pola yang penting atau menarik dari data dalam jumlah besar digunakan para pengambil keputusan dalam memanfaatkan gudang data. Proses penggalian ini menggunakan teknik statistik, matematika, kecerdasan buatan, dan machine learning untuk mengidentifikasi informasi yang bermanfaat dan pengetahuan yang terkait dari berbagai basis data besar, disebut juga sebagai data mining. (Anggraeni, Saputra, \& Noranita, 2013)

Dalam dunia bisnis, persaingan antar perusahaan untuk memasarkan produk tidak bisa dilepaskan dari pemanfaatan teknologi informasi. Salah satu sumber informasi yang dapat digunakan untuk membantu kegiatan penjualan perusahaan adalah sistem database. Cara untuk mendapatkan informasi berharga dari data transaksi adalah dengan menggunakan metode data mining. Data Mining merupakan suatu proses otomatis atau semi otomatis untuk menemukan informasi (knowledge) baru yang memiliki potensi dari sekumpulan data. (Kurniasih, Kumaladewi, \& Katjong, 2012)

Salah satu metode data mining adalah aturan asosiasi dengan melakukan analisis suatu transaksi penjualan. Analisis transaksi penjualan bertujuan untuk merancang strategi penjualan atau pemasaran yang efektif dengan memanfaatkan data transaksi penjualan yang telah tersedia di perusahaan. Selain itu, penggunaan teknik analisis ini juga dapat menemukan pola berupa produk-produk yang sering dibeli bersamaan atau produk yang cenderung muncul bersama dalam sebuah transaksi dari data transaksi yang pada umumnya berukuran besar. Perusahaan lalu dapat menggunakan pola ini untuk menempatkan produk yang sering dibeli ke dalam sebuah area yang berdekatan, merancang tampilan produk di katalog, merancang kupon diskon bagi pelanggan yang membeli produk tertentu, merancang penjualan paket produk, dan sebagainya. (Anggraeni et al., 2013)

Secara sederhana data mining adalah penambangan atau penemuan informasi baru dengan mencari pola atau aturan tertentu dari sejumlah data yang sangat besar. Data mining juga disebut sebagai serangkaian proses untuk menggali nilai tambah berupa pengetahuan yang selama ini tidak diketahui secara manual dari 
IN F ORM A T IK

Jurnal Informatika, Manajemen dan Komputer, Vol. 9, No. 2, Desember 2017

eISSN : 2580-3042

pISSN : 1979-0694

suatu kumpulan data. Data mining, sering juga disebut sebagai knowledge discovery in database (KDD). KDD adalah kegiatan yang meliputi pengumpulan, pemakaian data, historis untuk menemukan keteraturan, pola atau hubungan dalam set data berukuran besar. (Meilani, Dwi, \& Azmuri, 2015)

Karakteristik data mining sebagai berikut:

a. Data mining berhubungan dengan penemuan sesuatu yang tersembunyi dan pola data tertentu yang tidak diketahui sebelumnya.

b. Data mining biasa menggunakan data yang sangat besar. Biasanya data yang besar digunakan untuk membuat hasil lebih dipercaya.

c. Data mining berguna untuk membuat keputusan yang kritis, terutama dalam strategi.

Tujuan yang akan dicapai dalam penelitian ini adalah sebagai berikut:

1. Menerapkan algoritma FP-Growth untuk menentukan strategi pemasaran dan keterkaitan antara pupuk yang dijual sehingga dapat meningkatkan pelayanan kepada konsumen.

2. Menguji hasil dari data mining menggunakan aplikasi Rapidminer-studio7.3.0 dalam menentukan pola korelasi produk pupuk untuk meningkatkan penjualan.

3. Menghasilkan beberapa hubungan antara variable atau item berdasarkan implementasi dari algoritma FP-Growth.

4. Menguji hubungan variable atau item untuk mendapatkan pengetahuan baru dari proses ekstraksi menggunakan Tools yang ada.

\section{METODOLOGI PENELITIAN}

Metodologi penelitian merupakan urutanurutan yang dilakukan dalam melakukan sebuah penelitian. Metodologi ini bertujuan agar penelitian bisa lebih terkonsep dan terarah sesuai dengan tujuan yang diharapkan terhadap penelitian tersebut. Metodologi penelitian ini kemudian digambarkan ke dalam bentuk sebuah kerangka kerja. Berdasarkan pedoman dari kerangka kerja inilah penelitian akan dilakukan. Kerangka kerja ini akan dimulai dari melakukan studi pendahuluan hingga nantinya akan menghasilkan sebuah sistem yang setelah diuji dapat memenuhi tujuan dan memecahkan permasalahan yang diteliti. 
I N F O R M A T I K A

Jurnal Informatika, Manajemen dan Komputer, Vol. 9, No. 2, Desember 2017

eISSN : 2580-3042

pISSN : 1979-0694

dataset, setelah itu menentukan header frequent itemset dan membuat FP-Tree, kemudian FP-

Tree yang ada digunakan untuk membuat Conditional Pattern. Dari Conditional Pattern kemudian dilakukan penentuan Frequent Itemset.Dataset penelitian yang diambil adalah data transaksi penjualan pupuk pada tanggal 02 Januari 2017-11 Januari 2017 yang dapat dilihat pada tabel 1 .

Tabel 1. Dataset Transaksi Penjualan Pupuk

\begin{tabular}{|c|c|c|}
\hline Tanggal & Kode & Nama Pupuk \\
\hline \multirow{2}{*}{ 02/01/2017 } & PO1 & PONSKA/NPK \\
\hline & NP12 & NPK MUTIARA ( KG \\
\hline \multirow{5}{*}{ 03/01/2017 } & UR7 & UREA PUTIH ( KG ) \\
\hline & $\mathrm{KC} 2$ & $\mathrm{KCL}(\mathrm{SAK})$ \\
\hline & $\mathrm{ZA} 2$ & ZA ( SAK ) \\
\hline & $\mathrm{KC} 1$ & $\mathrm{KCL}(\mathrm{KG})$ \\
\hline & NP12 & NPK MUTIARA ( KG \\
\hline \multirow{4}{*}{ 04/01/2017 } & NP12 & NPK MUTIARA ( KG \\
\hline & UR4 & UREA KALTIM \\
\hline & $\mathrm{KC} 1$ & KCL ( KG ) \\
\hline & UR7 & UREA PUTIH ( KG ) \\
\hline \multirow{3}{*}{ 05/01/2017 } & $\mathrm{KC} 1$ & $\mathrm{KCL}(\mathrm{KG})$ \\
\hline & NP12 & NPK MUTIARA ( KG \\
\hline & UR7 & UREA PUTIH ( KG ) \\
\hline \multirow{3}{*}{ 06/01/2017 } & $\mathrm{KC} 2$ & KCL ( SAK ) \\
\hline & NP12 & NPK MUTIARA ( KG \\
\hline & NP7 & NPK MAHKOTA \\
\hline \multirow{2}{*}{ 07/01/2017 } & PI1 & PIL NENAS \\
\hline & NP12 & NPK MUTIARA ( KG \\
\hline \multirow{6}{*}{ 08/01/2017 } & $\mathrm{KC} 1$ & KCL ( KG ) \\
\hline & DO2 & DOLOMIT BR ( SAK \\
\hline & UR7 & UREA PUTIH ( KG ) \\
\hline & PI1 & PIL NENAS \\
\hline & NP12 & NPK MUTIARA ( KG \\
\hline & TS1 & TSP ( KG ) \\
\hline \multirow{4}{*}{ 09/01/2017 } & NP12 & NPK MUTIARA ( KG \\
\hline & $\mathrm{KC} 1$ & KCL ( KG ) \\
\hline & DO6 & DOLOMIT RS ( SAK \\
\hline & UR7 & UREA PUTIH ( KG ) \\
\hline \multirow{6}{*}{$10 / 01 / 2017$} & UR4 & UREA KALTIM \\
\hline & TS2 & TSP ( SAK ) \\
\hline & PI1 & PIL NENAS \\
\hline & UR7 & UREA PUTIH ( KG ) \\
\hline & NP12 & NPK MUTIARA ( KG \\
\hline & NP7 & NPK MAHKOTA \\
\hline \multirow{6}{*}{$11 / 01 / 2017$} & DO4 & DOLOMIT M 100 \\
\hline & NP12 & NPK MUTIARA ( KG \\
\hline & UR2 & UREA ( SAK ) \\
\hline & UR7 & UREA PUTIH ( KG ) \\
\hline & $\mathrm{KC} 2$ & $\mathrm{KCL}(\mathrm{SAK})$ \\
\hline & UR4 & UREA KALTIM \\
\hline
\end{tabular}

Pada tabel 1 tersebut ada 10 dataset yang akan diolah dengan menggunakan Frequent Pattern Growth (FP-Growth). Frekuensi

kemunculan tiap item dari data transaksi dapat dilihat pada tabel 2 .

Tabel 2. Frekuensi Kemunculan Ke 1 Dan Support Tiap Item

\begin{tabular}{|c|c|c|c|}
\hline Kode & Nama Pupuk & Freq & $\begin{array}{l}\text { Support } \\
(\%)\end{array}$ \\
\hline PO1 & $\begin{array}{l}\text { PONSKA/NPK } \\
\text { MERAH ( KG ) }\end{array}$ & 1 & $10 \%$ \\
\hline NP12 & $\begin{array}{l}\text { NPK MUTIARA ( } \\
\text { KG ) }\end{array}$ & 10 & $100 \%$ \\
\hline UR7 & $\begin{array}{l}\text { UREA PUTIH } \\
\text { KG })\end{array}$ & 7 & $70 \%$ \\
\hline $\mathrm{KC} 2$ & KCL ( SAK ) & 3 & $30 \%$ \\
\hline ZA2 & ZA ( SAK ) & 1 & $10 \%$ \\
\hline $\mathrm{KC} 1$ & $\mathrm{KCL}(\mathrm{KG})$ & 5 & $50 \%$ \\
\hline UR4 & $\begin{array}{l}\text { UREA KALTIM ( } \\
\text { SAK ) }\end{array}$ & 3 & $30 \%$ \\
\hline NP7 & $\begin{array}{l}\text { NPK MAHKOTA ( } \\
\text { KG ) }\end{array}$ & 2 & $20 \%$ \\
\hline PI1 & PIL NENAS & 3 & $30 \%$ \\
\hline DO2 & $\begin{array}{l}\text { DOLOMIT BR } \\
\text { SAK ) }\end{array}$ & 1 & $10 \%$ \\
\hline TS1 & TSP ( KG ) & 1 & $10 \%$ \\
\hline DO6 & $\begin{array}{l}\text { DOLOMIT RS } \\
\text { SAK ) }\end{array}$ & 1 & $10 \%$ \\
\hline TS2 & TSP ( SAK ) & 1 & $10 \%$ \\
\hline DO4 & $\begin{array}{l}\text { DOLOMIT M } 100 \text { ( } \\
\text { SAK ) }\end{array}$ & 1 & $10 \%$ \\
\hline UR2 & UREA ( SAK ) & 1 & $10 \%$ \\
\hline
\end{tabular}

Pada tabel 2 dapat dilihat hasil frekuensi kemunculan item produk pupuk, selanjutnya dilakukan penentuan support. Pada penelitian ini diambil support count $30 \%$. Nilai support count akan mempengaruhi item yang akan dianalisa ketahap pembuatan FP-Tree dan dapat diketahui nilai support tertinggi serta dapat diketahui nilai support $(\%) \geq 30 \%$ yang memenuhi frekuensi $\geq 3$ dan selanjutnya data yang memenuhi support count diurutkan berdasarkan frekuensinya, yaitu pada tabel 3. Item yang memenuhi minimum support akan dilanjutkan untuk proses FPGrowth.

Tabel 3. Frekuensi Kemunculan ke 2

\begin{tabular}{llll}
\hline Kode & Nama Pupuk & Freq & $\begin{array}{l}\text { Support } \\
(\%)\end{array}$ \\
\hline NP12 & $\begin{array}{l}\text { NPK MUTIARA } \\
\text { ( KG ) }\end{array}$ & 10 & $100 \%$ \\
UR7 & UREA PUTIH ( 7 & $70 \%$ \\
& KG ) & & \\
KC1 & KCL ( KG ) & 5 & $50 \%$ \\
KC2 & KCL ( SAK ) & 3 & $30 \%$ \\
PI1 & PIL NENAS & 3 & $30 \%$ \\
UR4 & UREA KALTIM ( 3 & $30 \%$ \\
& SAK ) \\
\hline
\end{tabular}


IN F O R M A T I A

Jurnal Informatika, Manajemen dan Komputer, Vol. 9, No. 2, Desember 2017

eISSN : 2580-3042

pISSN : 1979-0694

Setelah dilakukan pemindaian data, pada kemunculan kedua menjadi data transaksi dalam pengolahan data mining,

Tabel 4. Data Transaksi Setelah Pemindaian

\begin{tabular}{ll}
\hline TID & Data Pupuk yang sudah diurutkan \\
\hline 1 & NP12 \\
2 & NP12, UR7, KC1, KC2 \\
3 & NP12, UR7, KC1, UR4 \\
4 & NP12, UR7, KC1 \\
5 & NP12, KC2 \\
6 & NP12, PI1 \\
7 & NP12, UR7, KC1, PI1 \\
8 & NP12, UR7, KC1 \\
9 & NP12, UR7, PI1, UR4 \\
10 & NP12, UR7, KC2, UR4 \\
\hline
\end{tabular}

Pada tabel 4 dapat dilihat data transaksi setelah pemindaian dan diurutkan berdasarkan nilai frekuensi.

\section{Pembentukan Frequent Pattern Tree (FP- Tree)}

Setelah item-item frequent didapat maka yang memenuhi nilai minimum support maka pembangkitan FP-Tree dapat dilakukan. Data akan diolah secara manual sesuai dengan konsep data mining dengan menggunakan algoritma Frequent Pattern Growth (FP-Growth). Setelah data diurut dapat dilanjutkan ke tahap pembangkitan FP-Tree. Pembacaan TID 1 (transaksi pertama), kemudian dilanjutkan dengan pembacaan TID2 (transaksi kedua), dan dilanjutkan transaksi selanjutnya hingga transaksi terakhir. Pembacaan TID atau pembangkitan FPTree dapat dilihat dari penjelasan berikut:

A. Pembacaan TID 1

Pada transaksi pertama atau TID 1 terdapat item $\{$ NP12 $\}$ yang kemudian membentuk lintasan null $\rightarrow$ NP12 dengan support count awal bernilai 1 . Pembacaan TID 1 dapat dilihat pada gambar 3. Kemudian dilanjutkan dengan pembacaan TID 2.

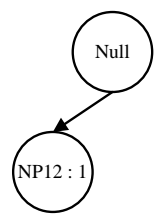

Gambar 3. Hasil Pembentukan FP-Tree Setelah Pembacaan TID 1

B. Pembacaan TID 2

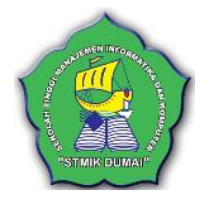

Pada transaksi kedua atau TID 2 terdapat item \{NP12, UR7, KC1, KC2 $\}$ sehingga support count NP12 bertambah satu menjadi 2 dan akan membentuk lintasan baru untuk item UR7, KC1, KC2 dengan support count awal 1. Pembacaan TID 2 dapat dilihat pada gambar 4.2. Kemudian dilanjutkan dengan pembacaan TID 3.

C. Pembacaan TID 3

Pada transaksi ketiga atau TID 3 terdapat item \{NP12, UR7, KC1, UR4\} sehingga support count NP12 bertambah satu menjadi 3, UR7 bertambah satu menjadi 2, $\mathrm{KC} 1$ bertambah satu menjadi 2 dan akan membentuk lintasan baru untuk item UR4 dengan support count awal 1. Pembacaan TID 3 dapat dilihat pada gambar 4.3. Kemudian dilanjutkan dengan pembacaan TID 4.

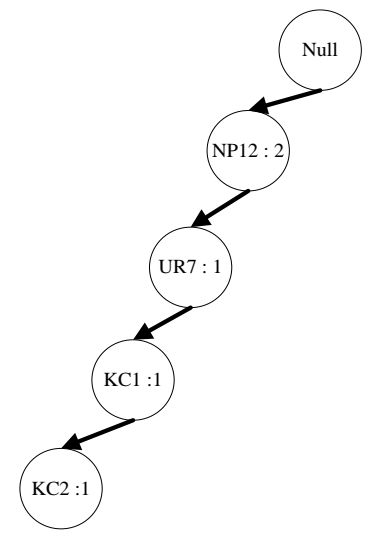

Gambar 4. Hasil Pembentukan FP-Tree Setelah Pembacaan TID 2

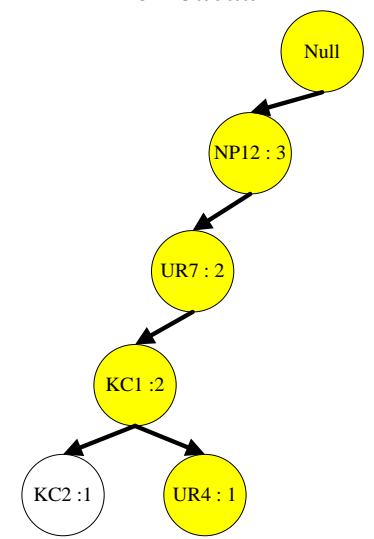

Gambar 5. Hasil Pembentukan FP-Tree Setelah Pembacaan TID 3

D. Pembacaan TID 4

Pada transaksi keempat atau TID 4 terdapat item $\{\mathrm{NP12}, \mathrm{UR7}, \mathrm{KC} 1\}$ sehingga lintasan NP12 bertambah satu menjadi 4, UR7 bertambah satu menjadi $3, \mathrm{KC} 1$ bertambah satu menjadi 3. Pembacaan TID 4 dapat 
IN F O R M A T I A

Jurnal Informatika, Manajemen dan Komputer, Vol. 9, No. 2, Desember 2017

eISSN : 2580-3042

pISSN : 1979-0694

dilihat pada gambar 4.4. Kemudian dilanjutkan dengan pembacaan TID 5.

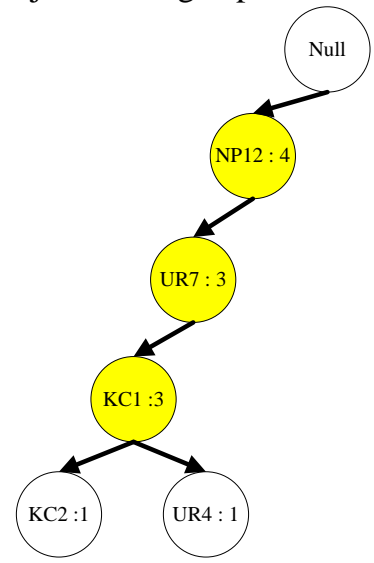

Gambar 6. Hasil Pembentukan FP-Tree Setelah Pembacaan TID 4

E. Pembacaan TID 10

Pada transaksi kesembilan atau TID 10 terdapat item \{NP12, UR7, KC2, UR4 sehingga support count NP12 bertambah satu menjadi 10, UR7 bertambah satu menjadi 7, dan akan membentuk lintasan baru untuk item KC2 dan UR4 dengan support count awal 1. Pembacaan TID 10 dapat dilihat pada gambar 4.

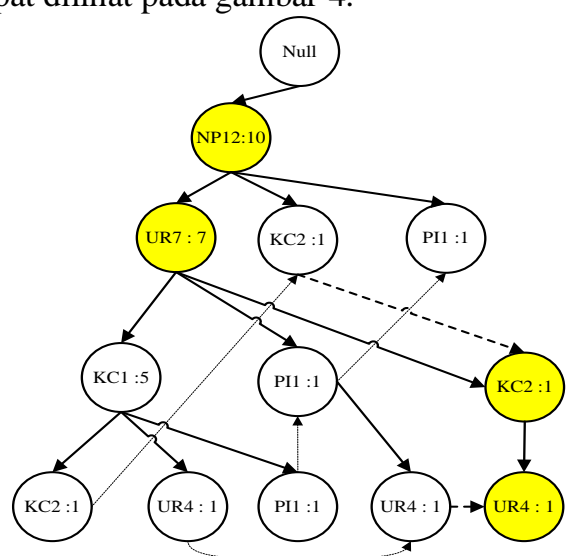

Gambar 7. Hasil Pembentukan FP-Tree Setelah Pembacaan TID 10

Ada 10 pembacaan TID dari hasil transaksi dengan terbentuknya 10 FP-Tree. Setelah proses pembangkitan FP-Tree maka selanjutnya yang akan dilakukan adalah penerapan FP-Growth.

\section{Penerapan FP-Growth}

Setelah dilakukan pembangkitan FP-Tree dari sekumpulan transaksi yang telah dilakukan, pada tahapan selanjutnya penerapan FP-Growth untuk mencari frequent itemset yang memenuhi syarat. Langkah FP-Growth ada 3 langkah utama

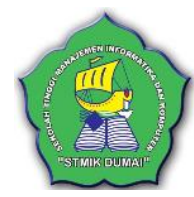

yaitu Conditional Pattern Base, Pembangkitan Conditional FP-Tree, dan Pencarian Frequent Itemset.

\section{a) Pembangkitan Conditional Pattern Base}

Tabel 5. Conditional Patern Base

\begin{tabular}{|c|c|c|}
\hline Item & \multicolumn{2}{|c|}{ Conditional Patern Base } \\
\hline UR4 & $\begin{array}{l}\{\{\mathrm{NP} 12, \quad \text { UR7, } \\
\text { PI1:1 }\},\{\text { NP12, UR7 }\end{array}$ & $\begin{array}{l}\},\{\text { NP12, UR7, } \\
2: 1\}\}\end{array}$ \\
\hline PI1 & $\begin{array}{l}\{\{\mathrm{NP} 12, \quad \text { UR7, } \\
\text { UR7:1\},\{NP12:1 }\}\}\end{array}$ & $\mathrm{KC} 1: 1\},\{\mathrm{NP} 12$ \\
\hline $\mathrm{KC} 2$ & 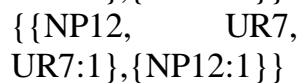 & $\mathrm{KC} 1: 1\},\{\mathrm{NP} 12$, \\
\hline $\mathrm{KC} 1$ & $\{\mathrm{NP} 12, \mathrm{UR} 7: 5\}$ & \\
\hline UR7 & $\{N P 12: 6\}$ & \\
\hline
\end{tabular}

b) Pembangkitan Conditional FP-Tree

Untuk menemukan frequent itemset dari tabel 3, maka perlu ditentukan terlebih dahulu lintasan yang berakhiran dengan support count terkecil, yaitu UR4 yang diikuti dengan PI1, KC2, KC1, UR7, NP12. Setelah tahap pembangkitan conditional pattern base dilakukan maka langkah selanjutnya adalah tahap pembangkitan conditional FP Tree. Pada tahap ii juga dilakukan dengan melihat FP Tree yang sudah dibentuk sebelumnya. Conditional FP Tree dimaksudkan untuk mencari frequent itemset yang berakhiran item tertentu atau mengandung suffix yang sama.

\section{c) Pencarian Frequent Itemset}

Setelah memeriksa frequent itemset untuk akhiran (suffix), maka dapatlah hasil secara keseluruhan yang terlihat dalam tabel 6 .

Tabel 6. Tabel Hasil Frequent Itemset

\begin{tabular}{ll}
\hline Suffix & Frequent itemset \\
\hline $\mathrm{UR} 4$ & $\{\mathrm{UR} 4\},\{\mathrm{NP} 12, \mathrm{UR} 4\},\{\mathrm{UR} 7, \mathrm{UR} 4\}$, \\
& $\{\mathrm{UR} 7, \mathrm{KC} 1, \mathrm{UR} 4\}$, \\
& $\{\mathrm{UR} 7, \mathrm{PI} 1, \mathrm{UR} 4\}$, \\
& $\{\mathrm{NP} 12, \mathrm{UR} 7, \mathrm{UR} 4\},\{\mathrm{KC} 1, \mathrm{UR} 4\}$, \\
& $\{\mathrm{PI} 1, \mathrm{UR} 4\},\{\mathrm{KC} 2, \mathrm{UR} 4\}$ \\
& $\{\mathrm{PI} 1\}, \quad\{\mathrm{NP} 12, \mathrm{PI} 1\}$, \\
& $\{\mathrm{NP} 12, \mathrm{UR} 7, \mathrm{PI} 1\},\{\mathrm{UR} 7, \mathrm{KC} 1, \mathrm{PI} 1\}$, \\
& $\{\mathrm{UR} 7, \mathrm{PI} 1\},\{\mathrm{KC} 1, \mathrm{PI} 1\}$ \\
& $\{\mathrm{KC} 2\}$, \\
& $\{\mathrm{NP} 12, \mathrm{UR} 7, \mathrm{KC} 2\}, \quad\{\mathrm{NP} 12, \mathrm{KC} 2\}$, \\
& $\{\mathrm{UR} 7, \mathrm{KC} 1, \mathrm{KC} 2\}, \quad\{\mathrm{KC} 1, \mathrm{KC} 2\}$, \\
KC1 & $\{\mathrm{UR} 7, \mathrm{KC} 2\}$ \\
& $\{\mathrm{NP} 12, \mathrm{~N} 12, \mathrm{UR} 1, \mathrm{KC} 1\}$ \\
$\mathrm{UR} 7 \quad$ & $\{\mathrm{UR} 7\},\{\mathrm{NP} 12, \mathrm{UR} 7\}$ \\
$\mathrm{NP} 12$ & $\{\mathrm{NP} 12\}$ \\
\hline
\end{tabular}




\section{N F O R M A I K}

Jurnal Informatika, Manajemen dan Komputer, Vol. 9, No. 2, Desember 2017

eISSN : 2580-3042

pISSN : 1979-0694

Pencarian Association Rules dilakukan melalui dua tahap yaitu pencarian frequent itemset dan penyusutan rules. Penting tidaknya suatu Association Rules dapat diketahui dengan dua parameter, yaitu support (nilai penunjang) dengan nilai min support $30 \%$ dan confidence (nilai kepastian) dengan minimum confidence $40 \%$. Support adalah ukuran yang menunjukan tingkat dominasi itemset dari kesuluruhan transaksi.

Setelah didapat frequent itemset, selanjutnya membuat rules dengan cara menghitung confidence dari tiap kombinasi rule. Dari 10 itemset yang dihasilkan pada tabel 6 tidak semua dihitung karena rule yang dihasilkan adalah jika A maka B, sehingga itemset yang dihitung minimal berisi dua item. Maka yang dihitung confidence-nya adalah 22 subsets, yaitu :

\{NP12,UR4\}, \{UR7,UR4\}, \{UR7,KC1,UR4\}, \{UR7,PI1,UR4\}, $\{\mathrm{NP} 12, \mathrm{UR} 7, \mathrm{UR} 4\}$, KKC1,UR4 $\}, \quad\{\mathrm{PI} 1, \mathrm{UR} 4\}, \quad\{\mathrm{KC} 2, \mathrm{UR} 4\}$, \{NP12,PI1\}, \{NP12,UR7,PI1\}, \{UR7,KC1,PI1\}, \{UR7,PI1 $, \quad\{\mathrm{KC} 1, \mathrm{PI} 1\}, \quad\{\mathrm{NP} 12, \mathrm{KC} 2\}$, \{NP12,UR7,KC2,$\quad\{\mathrm{UR7}, \mathrm{KC} 1, \mathrm{KC} 2\}$, \{KC1,KC2 $, \quad\{\mathrm{UR} 7, \mathrm{KC} 2\}, \quad\{\mathrm{NP} 12, \mathrm{KC} 1\}$, \{UR7,KC1\}, \{NP12,UR7,KC1\}, \{NP12,UR7\}.

Dalam menentukan suatu association rule, terdapat ukuran yang menyatakan bahwa suatu informasi atau knowledge dianggap menarik (interestingness measure). Ukuran ini didapatkan dari hasil pengolahan data dengan perhitungan tertentu. Untuk mengukur interestingness measure, dapat digunakan variable berikut ini :

a. Support

Suatu ukuran yang menunjukan berapa besar tingkat dominasi suatu item atau itemset dari keseluruhan transaksi. Ukuran ini menentukan apakah suatu item atau itemset layak dicari confidence-nya (misalnya, dari keseluruhan transaksi yang ada, seberapa besar tingkat dominasi yang menunjukkan bahwa item A dibeli bersamaan dengan item B). (Sumangkut, Lumenta, \& Tulenan, 2016)

Support $(A, B)=$ $\frac{\text { Jumlah Transaksi Mengandung A dan B }}{\text { Total Transaksi }} \times 100 \%$

\section{b. Confidence}

Suatu ukuran yang menunjukan hubungan antar dua item secara conditional (misalnya, seberapa sering item B dibeli jika pelanggan membeli item A).

Confidence $(A \rightarrow B)=$

Jumlah Transaksi Mengandung A dan B Jumlah Transaksi Mengandung A

Dari perhitungan nilai support dan confidence setiap association rule yang dilalui, maka didapat hasil yang dapat dilihat pada tabel 7.

Tabel 7. Kombinasi dan Interesting (Yes) Minimum Confidence

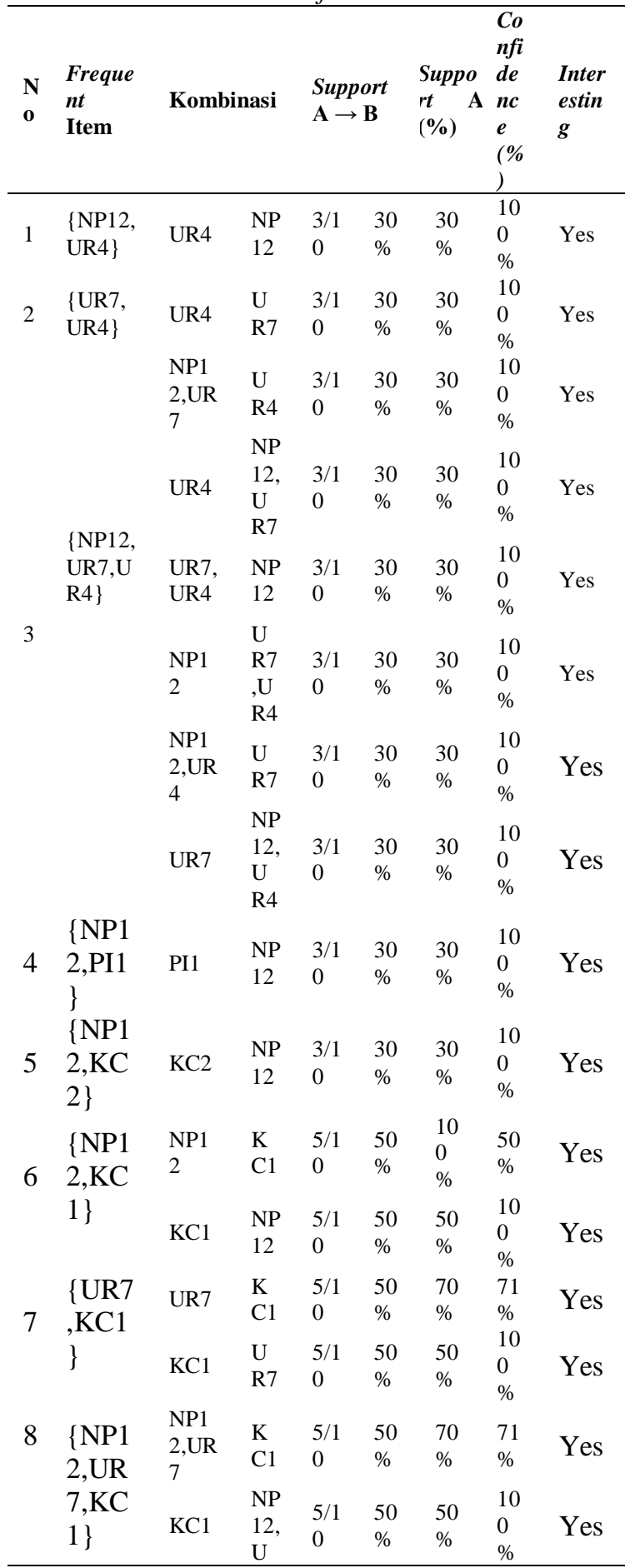


I N F ORM A T I K

Jurnal Informatika, Manajemen dan Komputer, Vol. 9, No. 2, Desember 2017

eISSN : 2580-3042

pISSN : 1979-0694

\begin{tabular}{|c|c|c|c|c|c|c|c|c|}
\hline & & & R7 & & & & & \\
\hline & & $\begin{array}{l}\text { UR7, } \\
\text { KC1 }\end{array}$ & $\begin{array}{l}\text { NP } \\
12\end{array}$ & $\begin{array}{l}5 / 1 \\
0\end{array}$ & $\begin{array}{l}50 \\
\%\end{array}$ & $\begin{array}{l}50 \\
\%\end{array}$ & $\begin{array}{l}10 \\
0 \\
\%\end{array}$ & Yes \\
\hline & & $\begin{array}{l}\text { NP1 } \\
2\end{array}$ & $\begin{array}{l}\mathrm{U} \\
\mathrm{R} 7 \\
\mathrm{~K} \\
\mathrm{C} 1\end{array}$ & $\begin{array}{l}5 / 1 \\
0\end{array}$ & $\begin{array}{l}50 \\
\%\end{array}$ & $\begin{array}{l}10 \\
0 \\
\%\end{array}$ & $\begin{array}{l}50 \\
\%\end{array}$ & Yes \\
\hline & & $\begin{array}{l}\text { NP1 } \\
2, \mathrm{KC} \\
1\end{array}$ & $\begin{array}{l}\mathrm{U} \\
\mathrm{R} 7\end{array}$ & $\begin{array}{l}5 / 1 \\
0\end{array}$ & $\begin{array}{l}50 \\
\%\end{array}$ & $\begin{array}{l}50 \\
\%\end{array}$ & $\begin{array}{l}10 \\
0 \\
\%\end{array}$ & Yes \\
\hline & & UR7 & $\begin{array}{l}\mathrm{NP} \\
12, \\
\mathrm{~K} \\
\mathrm{C} 1\end{array}$ & $\begin{array}{l}5 / 1 \\
0\end{array}$ & $\begin{array}{l}50 \\
\%\end{array}$ & $\begin{array}{l}70 \\
\%\end{array}$ & $\begin{array}{l}71 \\
\%\end{array}$ & Yes \\
\hline 9 & $\begin{array}{l}\{\mathrm{NP} 1 \\
2, \mathrm{UR}\end{array}$ & $\begin{array}{l}\text { NP1 } \\
2\end{array}$ & $\begin{array}{l}\text { U } \\
\text { R7 }\end{array}$ & $\begin{array}{l}7 / 1 \\
0\end{array}$ & $\begin{array}{l}70 \\
\%\end{array}$ & $\begin{array}{l}10 \\
0 \\
\%\end{array}$ & $\begin{array}{l}70 \\
\%\end{array}$ & Yes \\
\hline & $7\}$ & UR7 & $\begin{array}{l}\text { NP } \\
12\end{array}$ & $\begin{array}{l}7 / 1 \\
0\end{array}$ & $\begin{array}{l}70 \\
\%\end{array}$ & $\begin{array}{l}70 \\
\%\end{array}$ & $\begin{array}{l}10 \\
0 \\
\%\end{array}$ & Yes \\
\hline
\end{tabular}

\section{KESIMPULAN}

Implementasi algoritma $F P$-Growth dalam penelitian ini dapat diambil kesimpulan sebagai berikut :

1. Hasil perhitungan nilai support dan nilai confidence dari rule yang dihasilkan maka diambil 2 rule dengan nilai tertinggi yaitu:

a. Jika dilakukan penjualan pada produk NPK MAHKOTA (KG) and TSP (KG) maka dilakukan penjualan pada produk UREA PUTIH (KG) dengan tingkat confidence $92,3 \%$ dan support $11 \%$ dari banyaknya transaksi yang dibeli secara bersamaan.

b. Jika dilakukan penjualan pada produk TSP (KG) and DOLOMIT BR (SAK) then dilakukan penjualan pada produk UREA PUTIH (KG) dengan tingkat confidence $88,9 \%$ dan support $8 \%$ dari banyaknya transaksi yang dibeli secara bersamaan.

2. Didapatkan aturan seperti ini maka untuk penjualan dapat menggunakan aturan tersebut dalam membuat strategi untuk meningkatkan penjualan.

3. Dengan menggunakan algoritma FPGrowth dan bantuan dari software Rapidminer didapatkan hasil berupa aturan (rules) yang merupakan kumpulan frequent itemset dengan nilai confidence yang tinggi.

\section{REFERENSI}

Gambar 5. Output Data

Beberapa rule yang diambil adalah sebagai berikut:

Rule20 : If konsumen membeli produk pupuk UREA PUTIH ( KG ) then konsumen membeli produk pupuk NPK MUTIARA ( KG ) dan KCL ( KG ) dengan tingkat kepercayaan $71 \%$ dan didukung oleh $50 \%$ dari data keseluruhan

Rule21 : If konsumen membeli produk pupuk NPK MUTIARA ( $\mathrm{KG}$ ) then konsumen membeli produk pupuk UREA PUTIH ( KG ) dengan tingkat kepercayaan $70 \%$ dan didukung oleh $70 \%$ dari data keseluruhan

Rule22 : If konsumen membeli produk pupuk UREA PUTIH ( KG ) then konsumen membeli produk pupuk NPK MUTIARA ( KG ) dengan tingkat kepercayaan $100 \%$ dan didukung oleh $70 \%$ dari data keseluruhan

Anggraeni, H. D., Saputra, R., \& Noranita, B. (2013). Aplikasi Data Mining Analisis Data Transaksi Penjualan Obat Menggunakan Algoritma Apriori (Studi Kasus Di Apotek Setya Sehat Semarang), 4(May), 1-8. Arifin, R. N. (2015). Implementasi Algoritma Frequent Pattern Growth (FPGROWTH) Menentukan Asosiasi Antar Produk (Study Kasus NADIAMART). Techno.Com: Jurnal Teknologi Informasi (e-Journal), ISSN: 2356-2579.

Budiana, A. (2016). Implementasi Data Mining Pada Penjualan Produk Di PT. FOCUS GAYA GRAHA Menggunakan Metode Association Rule. Komputa : Jurnal Ilmiah Komputer dan Informatika, ISSN: 20899033.

Dhika, H. (2015). Kajian Perancangan Rule Kenaikan Jabatan Pada PT. ABC. Simetris : Jurnal Teknik Mesin, Elektro dan Ilmu Komputer, pISSN: 2252-4983, Vol. 6, No. 2, Hal: 217-222. 
IN F ORM T I K A

Jurnal Informatika, Manajemen dan Komputer, Vol. 9, No. 2, Desember 2017

eISSN : 2580-3042

pISSN : 1979-0694

Fitriyani. (2015). Implementasi Algoritma FpGrowth Menggunakan Association Rule Pada Market Basket Analysis. Informatika, II(1), 296-305. Retrieved from http://ejournal.bsi.ac.id/ejurnal/index.php/ji /article/view/85

Kurniasih, F., Kumaladewi, N., \& Katjong, L. (2012). Analisa Dan Perancangan Data Mining Dengan Metode Market Basket Analysis Untuk Analisa Pola Belanja Konsumen pada Tendencies Store. Sistem Informasi, 5(1), 1-10. Retrieved from http://journal.uinjkt.ac.id/index.php/sistemi nformasi/article/view/280

Meilani, Dwi, B., \& Azmuri, W. (2015). Penentuan Pola Yang Sering Muncul Untuk Penerima Kartu Jaminan Kesehatan Masyarakat. Seminar Nasional "Inovasi Dalam Desain Dan Teknologi," 424-431. Miraldi, R. N., Rachmat, A., \& Susanto, B. (2014). Implementasi Algoritma FPGROWTH untuk Sistem Rekomendasi Buku di Perpustakaan UKDW. Jurnal Informatika, ISSN: 1693-7279, VoL. 10, No. 1, Hal: 29-39.

Purba, R. (2012, April). Data Mining : Masa Lalu, Sekarang Dan Masa Mendatang. Jurnal Sifo Mikroskil, ISSN: 1412-0100, Vol. 13, No. 1, Hal: 31-41.

Ririanti. (2014, Maret). Implementasi Algoritma FP-GROWTH Pada Aplikasi Prediksi Persediaan Sepeda Motor (Studi Kasus PT. PILAR DELI LABUMAS). Pelita Informatika: Informasi dan Informatika, ISSN: 2301-9425, Vol. 6, No. 1, Hal: 139144.

Sumangkut, K., Lumenta, A., \& Tulenan, V. (2016). Analisa Pola Belanja Swalayan Daily Mart Untuk Menentukan Tata Letak Barang Menggunakan Algoritma FPGrowth. Teknik Informatika, 8(1), 52-56. Retrieved from http://ejournal.unsrat.ac.id/index.php/infor matika/article/view/12300

Triyanto, W. A. (2014). Association Rule Mining Untuk Penentuan Rekomendasi Promosi Produk. Journal SIMETRIS, Vol.5(No.2), 121-126. 